УДК 574.4

КОНСОРЦІЯ ЯК ЕЛЕМЕНТАРНА ОДИНИЦЯ ЕВОЛЮЦІЇ ЕКОСИСТЕМ

\author{
Й. В. Царик \\ Львівський національний університет імені Івана Франка \\ вул. Грушевського, 4, Львів 79000, Україна \\ e-mail:zoomus@franko.Iviv.ua
}

У статті, на основі аналізу робіт О.В. Яблокова [5] щодо елементарної еволюційної одиниці еволюції екосистем та М.А. Голубця [1] про глобальність еволюційного процесу органічного світу, зроблена спроба розглянути і надати консорції ранг елементарної еволюційної одиниці еволюції екосистем. О.В. Яблоков запропонував розглядати як таку одиницю біогеоценоз. Ми вважаємо, що біогеоценоз є вищою ієрархічною екосистемою, ніж консорція, він дискретний (його межі виділяють за межами фрітоценозу) і розглядати його як елементарну еволюційну одиницю екосистеми недоцільно. На цю роль краще надаються популяційні консорції едифікаторних видів, у яких відбуваються коеволюційні та мікроеволюційні процеси. Зроблено висновок, що зміна екосистем не завжди супроводжується їхньою еволюцією.

Ключові слова: еволюція, екосистема, консорція, популяційна консорція, динаміка

Звернутися до питання еволюції екосистем нас спонукала робота О.В. Яблокова [5], яка стосується механізмів еволюції на екосистемному рівні організації життя. У цій статті О.В. Яблоков пропонує вважати елементарною еволюційною одиницею еволюції екосистем біогеоценоз, поняття якого було введене в літературу В.М. Сукачовим [4]. Суть цього поняття полягає в тому, що в межах конкретної території існує система, яка сформована з угруповань живих організмів (рослин, тварин, мікроорганізмів) і сукупності абіотичних фракторів (атмосфера, ґрунт), які пов'язані між собою кругообігом речовин та потоком енергії. Біогеоценоз - це стійка саморегулююча система. Межі біогеоценозу переважно визначаються межами конкретного фрітоценозу, відтак існує таке його трактування: біогеоценоз - це екосистема в межах фрітоценозу.

Згідно з уявленнями О.В. Яблокова, біосфера - це сукупність взаємопов'язаних біогеоценозів. У той же час біосфера - це єдина, унікальна екосистема Землі [1]. Відтак, згідно із логікою уявлень О.В. Яблокова, біогеоценоз - елементарна еволюційна одиниця еволюції екосистеми Біосфрери, а хто є еволюційною одиницею для парцелярної, ландшафтної та інших екосистем?

Ще один фракт, на який доцільно звернути увагу, а саме: біогеоценоз - це дискретна система, хоча дискретність її компонентів у природі виділити дуже важко.

ISSN 1996-4536 (print) • ISSN 2311-0783 (on-line) • Біологічні Студії / Studia Biologica • 2017 • Том 11/№2 • C. 141-144 
Зокрема, це стосується гетеротрофрних організмів, які живуть або живляться поза межами конкретного біогеоценозу. О.В. Яблоков вказує, що елементарним явищем еволюції біогеоценозу (БГЦ) є зміна стійкого його видового складу, елементарним матеріалом еволюції є генофонд популяцій, а елементарними факторами - механізми, які призводять до "смерті" старого і виникнення "нового” БГЦ (ценотичний відбір).

Варто вказати, що питання еволюції екосистем у 70-х роках минулого століття бурхливо обговорювали дослідники [6], але воно й до сьогодні ще не розв'язане.

Зараз про це питання мало міститься інформації як в іноземній літературі, так і у вітчизняній. Крім цього, часто динаміку екосистем розглядають як їхню еволюцію. У той же час динаміка екосистем, на думку М.А. Голубця [1], - це всі зміни, які $€$ зворотними, кількісними, тобто не виводять екосистему за межі її стійкості, а також за межі її стабільного розвитку та не супроводжуються перебудовою її кібернетичної пам'яті (норми реакції біотичних компонентів на дію факторів зовнішнього середовища). До динаміки екосистем доцільно залучити також їхні сукцесії (первинні, вторинні, автотрофні, гетеротрофні). Класифрікацію динамічних змін екосистем можна знайти в роботі М.А. Голубця [1, с.181-188].

До еволюційних змін доцільно залучити ті, які відображають поступальні якісно нові структурно-функціональні перебудови в екосистемі, зокрема, норм реакції біотичних компонентів на дію факторів зовнішнього середовища. М.А. Голубець не вважає за доцільне говорити про еволюцію екосистем після катастроф, суттєвого антропогенного впливу, техногенних девастацій тощо.

Повернемося до питання еволюції екосистем, опираючись власне на роботу М.А. Голубця [1], в якій це питання опрацьоване достатньо фундаментально. М.А. Голубець, зокрема, звернув увагу і на питання синтетичної еволюції, насамперед на те, що під час ії розгляду не беруть до уваги той факт, що елементарна еволюційна одиниця (популяція) не існує ізольовано від популяцій інших видів і середовища її існування, яке вона змінює, тобто еволюціонує весь цей комплекс. Що стосується екосистем, то основною їхньою рисою є забезпечення в них матеріально-енергетичного обміну, тобто постійного обміну речовиною, енергією та інформацією між біотичними компонентами й середовищем їхнього існування, а це може здійснюватися лише за умови постійного народження особин, їхньої смерті, синтезу та деструкції органіки, тобто еволюція в екосистемі притаманна всім її компонентам.

М.А. Голубець звертає увагу також на те, що популяційний підхід до пояснення механізмів еволюції екосистем не є достатнім для розкриття їхньої суті, оскільки вони (механізми) охоплюють організми, популяції й екосистеми та змінюють середовище існування.

М. Голубець також звертає увагу на те, що екосистеми можуть існувати сотні мільйонів років, між екосистемами відсутній природній добір, їхні структурно-функціональні ознаки та пам'ять (сукупність генофондів популяцій різних груп організмів) не передаються уздовж вектора часу через спадковість екосистем [1, с.196]. Біотична еволюція охоплює одночасно єдиним фронтом усі рівні організації живого (організмений, популяційно-видовий, екосистемний) і проявляється у явищах мікроеволюції, макроеволюції та еволюції екосистем. Слід вказати, що конкретних даних щодо еволюції екосистем обмаль. Деякі міркування щодо еволюції біосфери - унікальної екосистеми - подає Ю. Одум [3]. Тепер у літературі досить широко обговорюються питання змін екосистем в умовах трансформації середовища, зумовленої антропічною діяльністю [9], ролі біорізноманіття в цьому процесі, стійкості і стабільності [10].

ISSN 1996-4536 (print) • ISSN 2311-0783 (on-line) • Біологічні Студії / Studia Biologica • 2017 • Том 11/№2 • C. 141-144 
Пізнання еволюції екосистем - творення нових якісних змін, надзвичайно важке до розв'язання завдання, яке пов'язане зі складністю їхньої структури й ієрархії. У той же час елементарною екологічною системою (екосистемою), як ми неодноразово відзначали, $є$ консорція [7]. Можна побудувати єрархію екосистем за рівнем їхньої складності: перша - консортивна, друга - парцелярна, третя - біогеоценозна, четверта - ландшафтна, п'ята - біомна, а завершується цей ряд - біосферою [1]. Виходячи із ієрархії екосистем, можна стверджувати, що елементарний еволюційний акт відбувається в елементарній екосистемі - консорції, а не в біогеоценозі, як про це писав О.В. Яблоков [5]. Власне, в межах консорції відбувається процес коеволюції, тобто процес "взаємних селективних взаємовпливів одних на інших великих груп організмів, які перебувають в тісній екологічній взаємозалежності, таких як рослини і травоїдні, великі організми та їх мікроскопічні симбіонти, паразити та їх господаpi” [3]. Коеволюційні процеси на рівні популяційної консорції впливають на структурно-фрункціональні параметри парцелярних і біогеоценозних та інших екосистем.

Звичайно, значна роль у цьому процесі також належить абіотичним (кліматичним, едафрічним) чинникам. Що стосується еволюції ландшафтних, провінційних і біомних екосистем, то визначальними чинниками цього процесу є кліматичні умови, гороутворення, геоморфологічна перебудова територій, динаміка ареалів домінантних (едифікаторних видів) виявлених нами видів рослин і тварин та загальні еволюційні зміни біосфери [1].

Ми вважаємо, що зміна домінантних видів не є рушієм еволюції, на цю роль більше підходять едифікаторні, тобто ті, які фрормують середовище ценозу. Підтвердженням цього можуть бути наші дослідження консортивної структури біогеоценозу Rumicetum alpini в Чорногорі протягом трьох років, на основі яких була розроблена графрічна модель консортивної організації автотрофного його блоку [8]. Було встановлено, що складна консортивна структура характерна для едифікаторної популяції Rumex alpinus L. У субедифікаторів і компонентів вона спрощена за рахунок об'єднання консортів другого та третього компонентів, які $€$ спільними. Консорції в межах біогеоценозу слабо дискретні. Їхня дискретність проявляється лише в першому концентрі й лише за наявності невеликої кількості облігатних консортів.

У первинних умовах структура консорцій повночленна, її фрормують організми трьох концентрів. Взаємозв'язки між організмами мають адаптивний характер. Відчуження наземної маси едифікаторної популяції консортами не впливає на її життєздатність. Під час антропогенного впливу консортивна структура змінюється, особливо суттєві зміни відбуваються під час деградації едифікаторної популяції. Консортивна організація тоді стає неповночленною, суттєво підвищується роль консортів-фрітофрагів і зменшується - деструкторів. Враховуючи те, що гетеротрофні консорти $є$ також детермінантами консорцій, процес зміни едифікаторної автотрофної популяції призводить до зміни всього різноманіття консорцій в екосистемі будь-якого ієрархічного рівня.

Можна зробити припущення, що еволюція екосистем, яка відбувається під впливом як ендогенних, так і екзогенних чинників, зокрема, антропічних, спрямована на збереження в них різноманіття живого й ефективної трансформації речовин і енергії, тобто досягнення динамічного рівноважного стану.

Підводячи загальний підсумок, можемо констатувати, що елементарною еволюційною одиницею екосистем доцільно вважати популяційну консорцію едифікаторного виду (-ів), а не біогеоценоз. Зміну консортивної організації екосистем, яка відбувається протягом тривалого часу (кількох поколінь існування едифікаторних 
популяцій рослин - детермінантів консорцій) разом зі зміною абіотичного середовища доцільно розглядати як еволюцію екосистем.

Зміни структури екосистем, що відбуваються під впливом антропічних чинників, доцільно розглядати як дегресивні сукцесії, а відновлення їхньої структури після призупинення дії негативних впливів - як демутації. Цю групу змін доцільно вважати динамікою екосистем, а не їхньою еволюцією.

1. Holubets M.A. Ecosystemology. Lviv: Polly Co. Ltd., 2000: 316 p. (In Ukrainian).

2. Lavrenko E.M. On the levels of studying the organic world. Field Phytosociology. M.; L.: AS of USSR Publishing House, 1964. Vol. 1: 32-46. (In Russian).

3. Odum Y. Ecology. M.: Peace, 1985. Vol. 1 - 326 p., Vol. 2 - 376 p. (In Russian).

4. Sukachev V.M. Basic concepts of forest biogeocenology. Moscow: Nauka, 1964. P. 5-49 (In Russian).

5. Yablokov A.V. On the Mechanism of evolution at the ecosystem system of organizing life. Journal Society. Biol, 2017; 78(2): 74-80. (In Russian).

6. Yablokov A.V, Yusufov A.G. Evolutionary teaching. Moscow: Higher School, 1989. 335 p. (In Russian).

7. Tsaryk J.V., Tsaryk I.J. Consortium as in general boitic phenomenon. Visnyk of Lviv. Univ. Biology Series, 2002: 28; 163-169 (In Ukrainian).

8. Tsaryk J.V. Age structure of autotrophic components of biogeocoenoses and their organization. Structure of high-mountain phytocoenoses in the Ukrainian Carpathians, Kyiv: Naukova Dumka. P. 29-38. (In Ukrainian).

9. Rockstron J., Steffen W., Noone K., Persson A., Chapin F.,Lambin E., Lenten T. et al. A sate operating space fer humanty. Nature, 2009: 461; 472-475.

10. Grant F., Mergeag J., Santamaria J., Xaung, Wan A.D. Evolution and biodiversiti by: the evolutionary basis of biodiversity and it's potential to global change. Conference report. 1-19 March 2010. Retrieved.

\title{
CONSORTIUM AS AN ELEMENTARY UNIT OF ECOSYSTEMS EVOLUTION
}

\author{
J. V. Tsaryk \\ Ivan Franko National University of Lviv, 4, Hrushevskyi St., Lviv 79005, Ukraine \\ e-mail:zoomus@franko.Iviv.ua
}

In the paper, based on the analysis of works of O.V. Yablokov (2017) about the elementary unit of ecosystems evolution and of M.A. Golubets (2000) about the globality of the evolutionary process of the organic world the attempt to investigate and assign a rank of elementary unit of ecosystems evolution to consortium is made. O.V. Yablokov suggested to consider the biogeocenosis as such unit. We consider that biogeocenosis is a higher than ecosystem hierarchical ecosystem, it is discrete (its limits are distinguished beyond the limits of the phytocenosis) and regarding it as an elementary evolutionary unit of ecosystem is unsuitable. This role is more suitable for populational consortiums of the edificatorial species in which the coevolutional and microevolutional processes take place. The conclusion states that the evolution of the ecosystems does not always follow their transformation.

Keywords: evolution, ecosystem, consortium, populational consortium, dynamic

Одержано: 31.08.2017

ISSN 1996-4536 (print) • ISSN 2311-0783 (on-line) • Біологічні Студії / Studia Biologica • 2017 • Том 11/№2 • C. 141-144 